Table Details of children with valproate induced pancreatitis

\begin{tabular}{|c|c|c|c|c|c|c|c|c|c|}
\hline Source & $\begin{array}{l}\text { Age } \\
\text { (years) }\end{array}$ & $\operatorname{Sex}$ & Type of fits & Other diseases & $\begin{array}{l}\text { Recurrence on } \\
\text { re-exposure } \\
\text { to valproate }\end{array}$ & $\begin{array}{l}\text { Dose of } \\
\text { valproate } \\
\mathrm{mg} / \mathrm{kg}\end{array}$ & $\begin{array}{l}\text { Duration of } \\
\text { treatment to } \\
\text { onset of } \\
\text { pancreatitis }\end{array}$ & $\begin{array}{l}\text { Other drugs } \\
\text { given }\end{array}$ & Outcome \\
\hline This report & 1 & $\mathbf{F}$ & $\begin{array}{l}\text { Absence } \\
\text { Focal }\end{array}$ & $\begin{array}{l}\text { Vascular } \\
\text { disorder }\end{array}$ & Not tested & 25 & 6 dys & Nil & Died \\
\hline Camfield et $a l^{2}$ & 11 & $\mathbf{F}$ & Absence & $\begin{array}{l}\text { Meningitis at } \\
2 \mathrm{yrs}\end{array}$ & Yes & $\begin{array}{l}45 \\
25\end{array}$ & $\begin{array}{l}3 \mathrm{mth} \\
1 \frac{1}{2} \mathrm{mth}\end{array}$ & Nil & Survived \\
\hline Camfield et $a l^{2}$ & $3 \frac{1}{2}$ & $\mathbf{M}$ & Akinetic & $\begin{array}{l}\text { Premature; } \\
\text { Perinatal } \\
\quad \text { asphyxia; } \\
\text { Developmental } \\
\quad \text { retardation; } \\
\text { Infantile spasms }\end{array}$ & Not tested & 55 & 3 mth & Phenytoin & Survived \\
\hline Batalden et al $^{3}$ & 8 & $\mathbf{M}$ & Petit mal & Nil & Yes & $\begin{array}{l}30 \\
30\end{array}$ & $\begin{array}{l}5 \mathrm{wk} \\
6 \mathrm{mth}\end{array}$ & Nil & Survived \\
\hline Sasaki et al 4 & 11 & $\mathbf{F}$ & Absence & $\begin{array}{l}\text { Nephritis at } \\
7 \text { yrs }\end{array}$ & Yes & $\begin{array}{l}30 \\
20\end{array}$ & $\begin{array}{l}4 \mathrm{mth} \\
6 \mathrm{mth}\end{array}$ & Phenobarbitone & Survived \\
\hline $\begin{array}{l}\text { Coulter and } \\
\text { Allen } 5\end{array}$ & 8 & $\mathbf{M}$ & $\begin{array}{l}\text { Myoclonic } \\
\text { Akinetic }\end{array}$ & Nil & Yes & $\begin{array}{l}65 \\
20\end{array}$ & $\begin{array}{l}4 \mathrm{mth} \\
4 \mathrm{mth}\end{array}$ & $\begin{array}{l}\text { Phenytoin } \\
\text { Clonazepam }\end{array}$ & Survived \\
\hline $\begin{array}{l}\text { Coulter and } \\
\text { Allen } 5\end{array}$ & 10 & $\mathbf{F}$ & Not known & Not known & Not tested & 30 & $3 \mathrm{mth}$ & Nil & Died \\
\hline Parker et al 6 & 16 & $\mathbf{M}$ & Psychomotor & Nil & Yes & $\begin{array}{l}40 \\
40 \\
40 \\
40\end{array}$ & $\begin{array}{l}5 \mathrm{mth} \\
5 \mathrm{mth} \\
4 \mathrm{mth} \\
6 \mathrm{wk}\end{array}$ & $\begin{array}{l}\text { Carbamazepine } \\
\text { Methsuximide } \\
\text { Acetazolamide }\end{array}$ & Survived \\
\hline
\end{tabular}

had shown acute haemorrhagic pancreatitis, but no other details of this patient are given. ${ }^{5}$

Our patient developed pancreatitis at a younger age, after a shorter exposure to valproate than any other, and she was the only patient who was given sodium valproate rather than valproic acid. Necropsy confirmed acute haemorrhagic pancreatitis. The short time ( 6 days) between taking valproate and the onset of symptoms suggests a causal relation but the contribution, if any, of the vascular disease to the development of pancreatitis in this patient is not clear.

\footnotetext{
References

1 Sodium valproate re-assessed. Drug Ther Bull 1981; 19: 93-5.
}

2 Camfield PR, Bagnell P, Camfield CS, Tibbles JAR. Letter: Pancreatitis due to valproic acid. Lancet 1979; i: 1198-9.

3 Batalden PB, Van Dyne BJ, Cloyd J. Pancreatitis associated with valproic acid therapy. Pediatrics 1979; 64: 520-2.

4 Sasaki M, Tonoda S, Aoki Y, Katsumi M. Letter: Pancreatitis due to valproic acid. Lancet 1980; i: 1196.

5 Coulter DL, Allen RJ. Pancreatitis associated with valproic acid therapy for epilepsy. Ann Neurol 1980; 7:92.

- Parker PH, Helinek GL, Ghishan FK, Greene HL. Recurrent pancreatitis induced by valproic acid. Gastroenterology 1981 ; 80: 826-8.

Correspondence to $\mathrm{Dr}$ L H P Williams, Department of Paediatrics, Victoria Hospital, Worksop, Nottinghamshire S80 2BN.

Received 29 March 1983

\title{
Circumstances surrounding deaths from accidental poisoning 1974-80
}

\section{A W CRAFT}

\section{Children's Department, Royal Victoria Infirmary, Newcastle upon Tyne}

SUMMARY The deaths of 99 children under 5 years of age were studied through the coroners' records. Sixty nine deaths were caused by medicines-most of which were prescribed for mother, were recently dispensed, and currently in use. Household products accounted for 11 deaths, lead poisoning for 6 , carbon monoxide for 5 and 'medical mishaps' for 8. Prevention lies in both education and more effective and selective use of child resistant containers.
Each year accidental poisoning in children accounts for roughly 24000 hospital admissions, ${ }^{1}$ but fortunately few deaths. Much effort had been put into reducing this number but until the selective introduction of child resistant closures (CRCs) on drug containers in 1976 there was little change. ${ }^{2}$ The use of CRCs has now been extended by voluntary agreement to solid dose medicines dispensed by pharmacists but as there has been opposition from both the public and the medical and 
pharmaceutical professions, implementation is far from universal. Attempts have recently been made to extend the use of CRCs to household products. ${ }^{3}$ Childhood deaths fion poisoning in England and Wales from 1974 to 1980 are reviewed here in an attempt to identify those substances most commonly implicated and to determine circumstances surrounding these accidental poisonings that may give a lead towards prevention.

\section{Method}

Copies of death registration certificates and transcripts of the coroners' inquest proceedings were sought for all children under 5 years who died of poisoning between 1974 and 1980 in England and Wales. In those cases where the coroners' records were not available some information was obtained from the death certificate.

\section{Results}

Ninety nine children died during this period and the annual incidence is shown in Table 1 . Coroners' records were available for $84 \%$ of these deaths.

Medicinal products. Thirty five boys and 34 girls died as a result of poisoning with medicines. The drugs are listed in Table 2. In 57 cases it was possible to determine for whom the drug was prescribed: mother 33; father 3 ; the child 2; sibling 5; grandparent 7 ; uncle or aunt 5 ; and friend 2 . In 48 cases in which it was known when the medicine had been dispensed, $79 \%$ had been the previous month, and only 1 prescription was more than 24 months old. The medicine was currently in use in $\mathbf{4 1}$ cases but not in 11. In 48 cases the incident occurred in the child's own home and in 8 cases it occurred in the grandparents' home. Nineteen mothers were said to be depressed, 6 had suffered recent marital separation, and 6 mothers were either pregnant or had just had a baby.
Table 2 Poisonings caused by medicinal and household products in children aged under 5 years in England and Wales between 1974 and 1980

\begin{tabular}{l} 
Medicinal products \\
Antidepressants/tranquilisers \\
Tricyclics \\
Barbiturates \\
Chlorpromazine \\
Pericyazine \\
Other central nervous system drugs \\
Diphenoxylate (Lomotil) \\
Methadone \\
Orphenadrine \\
Dibenzepine \\
Ergotamine (Migril) \\
Analgesics \\
Salicylates \\
Paracetamol \& nitrazepam \\
Phenylbutazone \\
Others \\
Quinine/chloroquine \\
Potassium preparations \\
Iron \\
Digoxin \\
Fenfluramine \\
Isoniazid \& rifampicin \\
Pheniramine \\
Household products \\
Cresol (Wright's vaporising fluid) \\
Alcohol \\
Caustic soda \\
Corrosive acid \\
Ethylene chlorhydrine (cinecol film cement) \\
Phenol (Ibcol disinfectant) \\
Sodium chlorate \\
Sodium nitrite \\
Soldering flux \\
Total No \\
\hline
\end{tabular}

$33)$
26
5
1
1

Table 1 Deaths from accidental poisoning in children aged under 5 years in England and Wales between 1974 and 1980

\begin{tabular}{|c|c|c|c|c|c|c|c|c|c|}
\hline \multirow[t]{2}{*}{ Type of poisoning } & \multicolumn{8}{|c|}{ No of deaths } & \multirow{2}{*}{$\begin{array}{l}\text { No for which coroners } \\
\text { records were obtained }\end{array}$} \\
\hline & 1974 & 1975 & 1976 & 1977 & 1978 & 1979 & 1980 & Total no & \\
\hline $\begin{array}{l}\text { Medicinal } \\
\text { Non-medicinal } \\
\text { Lead } \\
\text { Carbon monoxide } \\
\text { Medical mishap }\end{array}$ & $\begin{array}{r}16 \\
4\end{array}$ & $\begin{array}{r}12 \\
3 \\
3 \\
1\end{array}$ & 12 & $\begin{array}{r}11 \\
1\end{array}$ & $\begin{array}{l}8 \\
2 \\
2\end{array}$ & $\begin{array}{l}5 \\
1 \\
1 \\
3 \\
1\end{array}$ & $\begin{array}{l}2 \\
3\end{array}$ & $\begin{array}{r}69 \\
11 \\
6 \\
5 \\
8\end{array}$ & $\begin{array}{r}60 \\
10 \\
5 \\
2 \\
6\end{array}$ \\
\hline Total No & 21 & 19 & 13 & 13 & 12 & 11 & 10 & 99 & 83 \\
\hline
\end{tabular}

Three children died after discharge from hospital where they had been treated for poisoning and 2 died after lack of appropriate action by parents even though they knew that the child had probably been poisoned.

Household products. Eleven children were poisoned with the substances shown in Table 2 . This number 
includes 1 child who swallowed corrosive acid in Kuwait and was brought to England for treatment. In 3 cases the poisonous substance was not in its original container, but was, for example, in an old lemonade bottle.

Lead poisoning. Six children died from lead encephalopathy. Four, judging by their names, were from immigrant families. All 6 were known to have eaten old paint, but 1 child may have been poisoned by the lead containing eye make up Surma. All 6 lived in old homes where there were many layers of paint. The outer layers were lead free but the inner ones contained high concentrations of lead.

Carbon monoxide. Five children died as a result of carbon monoxide poisoning: 3 because of a malfunctioning gas fire; 1 from car exhaust fumes; and 1 from an unknown source.

Medical 'mishaps'. Six newborn babies died after an excessive dose of digoxin (4) or chloramphenicol (2). A baby aged 3 months died of an overdose of digoxin and 1 child from morphine (nepenthe) poisoning. In these 8 cases 4 mistakes were made by nurses and 2 by doctors.

\section{Discussion}

Deaths from poisoning are declining but this is mainly because of a fall in the number of medicinal poisonings. Five substances account for 50 of the 69 deaths from medicinal poisoning and legislation should be introduced to extend the use of CRCs to tricyclic antidepressants, diphenoxylate (Lomotil), barbiturates, and chloroquine/quinine.

Attempts have previously been made to put all prescriptions dispensed for children in CRCs. In the period studied this would have prevented only 2 of the deaths as most of the drugs were prescribed for either parents or grandparents. Most of the children were poisoned with medicines prescribed during the preceding month that were currently in use, and this may be the reason for the failure of campaigns urging the return of old medicines. Grandparents' homes, where traditional safety measures may not be taken, are again seen as a risk to young children. ${ }^{4}$ The type of container was not stated on the coroners' records but it is unlikely that many were CRCs as this would almost certainly have attracted some comment. Family stress has been shown to be a factor in childhood poisoning and although it was possible to identify stress in many families, insufficient information was available to allow investigation of this problem. Although 19 mothers only were said to be depressed, 26 children were poisoned with tricyclic antidepressants, mostly prescribed for their mothers.

There were few non-medicinal poisoning deaths. In 3 the substance was not in its original container. It is unlikely that the introduction of CRCs for domestic products would do much to reduce this small number of poisonings but there should be more vigorous health education, which might also help to reduce lead poisoning deaths. Carbon monoxide poisoning accounted for 5 deaths but this number did not include children dying in fires.

The number of children who died as a result of 'medical mishaps' gives cause for much concern. Only 1 would inevitably have died of his disease. Seven deaths were due to errors in either dosage calculation and prescription or misinterpretation of the place of the decimal point. The mistakes made by nurses occurred despite adequate safety procedures that should have been followed but were circumvented. Constant vigilance of both doctors and nurses is needed if we are going to reduce these totally unnecessary deaths.

Prevention of poisoning deaths is not just a question of more CRCs. Several children might have survived had there been either better medical management or a greater awareness by parents of the dangers of poisoning in childhood. Constant education of all those dealing with children is needed to remind them of the dangers of poisoning and of the appropriate first aid and definitive management.

I thank Mr Geoffrey France and the Department of Trade; Dr J Burton of the Society of Coroners and the coroners who willingly supplied information; and Mrs Paula McEwen.

\section{References}

1 Department of Health and Social Security. Hospital inpatient enquiry for 1979. London: HMSO, 1981.

2 Jackson RH, Craft AW, Sibert JR. Childhood Poisoning-A review of policy and practice. Pharm $J$ 1981; 226: 239-40.

3 HM Government. Dangerous household products (child safety) packaging bill. Hansard 1982; 29 January: 1158-66.

- Sibert JR. Letter: Poisoning in children. Br Med J 1973; i: 803 .

Correspondence to Dr A W Craft, Children's Department, The Royal Victoria Infirmary, Queen Victoria Road, Newcastle upon Tyne NE1 4LP.

Received 14 February 1983 